\title{
Spliceosome RNA Helicase DDX39B
}

National Cancer Institute

\section{Source}

National Cancer Institute. Spliceosome RNA Helicase DDX39B. NCI Thesaurus. Code C118924.

Spliceosome RNA helicase DDX39B (428 aa, $49 \mathrm{kDa}$ ) is encoded by the human DDX39B gene. This protein plays a role in spliceosome assembly and the nuclear export of spliced and unspliced mRNA. 